\title{
Developing a Model of a Competency and Students Computer Network International Certification Test for Vocational High Schools
}

\author{
Hary Suswanto \\ Electrical Engineering Department, Engineering Faculty \\ Malang State University, Malang, INDONESIA \\ h_arias2000@yahoo.com
}

\begin{abstract}
This study aims: (1) to investigate the implementation of the available certification test; (2) to find out a model of a competency and students computer network international certification test by integrating a cognitive competency test and a psychomotor competency test; (3) to find out the validity index, the efficiency, and the effectiveness of the model appropriateness; and (4) as well as the effects of the use of the model in the computer network subject on the students' cognitive competencies and interests. This was a research and development $(\mathrm{R} \& \mathrm{D})$, referring to[2]. The tryout subjects in this study comprised Grade XII students of semester 5 in the computer network study program using the quasi-experimental method. The data were collected through a pretest and a posttest employing the dichotomous model and a Likert-model questionnaire with four scales. The tests of the instrument validity and reliablity referring to the students' cognitive competencies and interests used expert judgement, Pearson correlation, and Cronbach's alpha. The data were analyzed using the descriptive statistics and the t-test. Based on the results of the operational field tryout, it was condluded that: (1) the pretest scores of the experimental class and the control class were sigficantly the same ( $\mathrm{p} \geq 0.05)$; (2) the posttest better pretest scores of the experimental class were significantly the different $(\mathrm{p}$ $\leq 0.05$ ) was very efficient; (3) the posttest scores of the experimental class better of the control class were significantly the different ( $p \leq 0.05$ ) was effective; (4) the means good categories of the students' active competencies were: 74.58 for the cognitive aspect, 73.00 for the affective aspect, and 75.50 for the psychomotor aspect; and (5) the students' attitudes towards: the certification test process were positive $(80 \%)$, the materials of the certification test were positive $(90 \%)$, and the instructors/teachers of the certification test were positive $(80 \%)$.
\end{abstract}

Index Terms - model development, competency and certification test, computer network

\section{Introduction}

In 2020 year Indonesia entered the era of free trade, the industry required to follow the international regulations and market demands that require the hallmark of quality products with a high level of competition by placing human resources, governance and quality management technology as a key factor.

Development Directorate of Vocational High School (PSMK) has long pioneered efforts to comply with a competent workforce for Vocational High School (SMK) graduates through policy skills by 2020 for the global era. The implication is used to describe a curriculum based curriculum with study materials and testing associated with productive skills is based on the standard of expertise to actively involve the business and industrial world (Du/Di).
Faced with the possibility of future perspectives will be organizing the test of competence, competency testing and certification of computer networks of students performed at "SMK" has two sides interests, namely as a measure of achievement of the competence graduates, as well as the recognition of one's competence to do the job.

Reference [14] mentions that one of the characteristics of vocational education is to prepare students to enter the workforce, so that vocational education should be based on demand driven the need for the world of work.

A similar opinion was expressed by Reference [13], that the organization of vocational education should be focused and directed educational programs that lead to the readiness of the individual in order to prepare themselves as workers, whether paid or unpaid.

Reference [11] states that a more detailed opinion, the contents of the vocational education program was organized to prepare the individual or people to work (both work for wages or not), is to provide a set of core competencies which include skills in thinking and skills specific physical for work, so that later can contribute to the country's economy and in her life in the community.

Research Reference [11] states that, in order to improve its image, vocational education must be responsive to labor market needs and technological advances as well as the need to be more proactive in developing programs. Similarly, Reference [8] asserts that in educational planning approach uses the concept of education for employment, which attempts to direct the educational activities to meet national needs/areas for labor. The approach prioritizes graduates linkages with workforce needs, both in terms of the quantity and quality. Coombs in Reference [9] explains that the quality of vocational education if the students who have experienced educational process is unacceptable in the workplace according to their expertise.

February statistics in 2012 [1] suggests that the formation of the labor force in the industrial sector reached 14.21 million people or about $12.59 \%$ of the total employment figures reached 112.80 million. This situation suggests that the needs of the labor market in the industrial sector is still pretty big, and this provides an opportunity for graduates of vocational high school program of study especially in computer engineering and informatics, computer engineering competencies and networks.

In 2010 [7], the number of State and private vocational graduates in the province of East Java reached 138,000 
people, about $10 \%$ of them went to college, so that the economic growth of $1 \%$, then graduates of vocational high school in East Java, which is not absorbed approximately 50,000-60,000 people.

Preliminary studies in East Java province on the implementation of competency testing and certification in vocational shows that, certificate of vocational high school students and private land acquired through three models, namely: (1) final project (PTA), (2) competency test held by professional certification institute (LSP), and (3) industrial work practices (Prakerin). Certificates obtained from the implementation Prakerin and obtained a certificate of PTA is used as a complement to the national examination (UN) and the certificate obtained from the LSP is an additional provision for students who have to have in order to apply for jobs.

Empirical studies on the implementation of competency testing and certification of student computer networks, information was obtained that: (1) lack of availability of equipment for practical activities in competency testing and certification activities, (2) the tasks given by the instructors/teachers only solve the problems that in the competency test and certification modules, (3) providing feedback is rarely given by the instructors/teachers, (4) delivery of content competency tests and certification is still sentries teacher (teacher centered), (5) students in the process of delivering the test material is still a passive recipient of the information and have not been able to develop their own knowledge learned, (6) the students more as objects than as subjects delivery of test materials, and (7) are results-oriented assessment of competency testing and certification of students, not on the assessment of the competence of testing and certification.

Research Reference [12] on the model, the precision of the target, towards the achievement of competence, and opinions related to the implementation of the competency test in order to test students nationwide, concluded that: (1) as much as $74.28 \%$ of respondents asserted should be the implementation of student competency tests in order national exams continue to use the project approach work with internal and external verification, and as much as $36.52 \%$ of respondents provide an alternative to using the approach or model adopted by the professional certification institute-national professional certification board (LSPBNSP), (2) as much as $59.58 \%$ of respondents answered suitability assessors expertise located in the provincial capital, and $52.74 \%$ of respondents answered located in the district, (3) the majority of respondents said certification competency test students should be given by $\mathrm{Du} / \mathrm{Di}$, and a small portion given by the school, kadin, or professional association, (4) as much as $55.6 \%$ "Du/Di" the mention of competency standards used in testing student competence refers to the Indonesian national occupational competency standards (SKKNI), as much as $33.3 \% \mathrm{Du} / \mathrm{Di}$ the standard refers to BNSP, and as much as $11.1 \%$ refers to $\mathrm{Du} / \mathrm{Di}$, and (5) the basis for determining graduation competency test, most states refers to the provision repsonden UN, BNSP, and Du/Di standards.

Reference [4] in a study with the title model competency test at SMK stated that vocational high school as one of the institutions in the field of vocational education has the goal of preparing prospective workers who have the knowledge, skills and entrepreneurship skills to fill good jobs at the local, nationally and internationally.

The results Reference [5] on the development of competence in the test model based curriculum in Vocational School industrial technology group and concluded that the curriculum developed at SMK basically emphasizes multiple learning approaches, including: competency-based learning approach, based on production and complete learning (mastery learning).

Reference [16] in his study entitled competency model development test device specific SMK technology to support certification of engineering technicians in the industry reveal that specifically the 2 nd stage of research was done in order to implement and evaluate the implementation of the competency test device models in SMK technology, the 2nd stage of the research conducted in the field of industrial engineering and vocational technology.

Based on the background and results of the above empirical studies encourage researchers to develop a model of competency testing and certification of computer networks by integrating test students' cognitive competence and psychomotor competencies. This model is expected to provide an overview of the characteristics of competency testing and certification, providing improved delivery of content competency testing and certification, and enhance cognitive abilities and interests of students to the subject of computer networks.

Formulation of the problem in this study, namely: (1) how the implementation of the available certification test, (2) how the model of a competency and students computer network international certification test by integrating a cognitive competency test and a psychomotor competency test?, (3) how the devices model of a competency and students computer network international certification test by integrating a cognitive competency test and a psychomotor competency test to be effective and efficient?, and (4) how the skills and attitudes of students of SMK on the application of the devices model of a competency and students computer network international certification test by integrating a cognitive competency test and a psychomotor competency test?

\section{Methods}

The model is a pattern (eg, reference, range) of something that will be created, meaning something that represents or describes an emulated. Reference [15] defines that the model is a representation of a process in a graphical form, and or narrative, showing the main elements and structure. Reference [3] explains that the model is a set of procedures and sequence to create a process, so the test model is a set of competencies and certification procedures and sequence to melaksaakan the competency test and certification of vocational high school students.

This study is a research and development ( R \& D), using a model of the development of conceptual and procedural referring to Borg and Gall. The procedures performed were divided into two main groups, namely research and development activities. The research activity is to collect data and information on the product to be developed, while the development activities is to validate the products developed through focus group discussions (FGD), limited trial, and trials expanded. The operational field tryout was 
conducted in SMK Negeri 1 Purwosari, Pasuruan Regency, and SMK Negeri 2 Bojonegoro, Bojonegoro Regency. The tryout subjects in this study comprised Grade XII students of semester 5 in the computer network study program.

\section{Result and Discussion}

a. The Available of a Competency and Certification Test Competence is a combination of knowledge, skills, and attitudes that affect inter-related and performance-correlated with performance on the job, and can be measured by the standards agreed upon, and can be improved through training and development [10].

Implementation of the available of a competency and certification tets in SMK is a system of educational standards set by the national education standards agency (BSNP) includes eight national education standards (competency, content, process, educators and education personnel, facilities, management, education funding and assessment of education), [6] while the BNSP is the body that sets standards of competence productive vocational students, where both institutions have the goal of producing profiles SMK graduates competent to work in $\mathrm{Du} / \mathrm{Di}$, work independently (self-employed), or college to continue their studies.

Profile of graduates of SMK is currently described in the curriculum of SMK processes with emphasis more practice at $\mathrm{Du} / \mathrm{Di}$. Students who pass the exam will receive a diploma and can sign up for a competency test conducted by the LSP.

The weakness models competency test conducted by the available of the LSP, are: (1) not all the students of SMK can competency test in LSP, this is because not all areas have LSP which can serve competency testing and certification of vocational high school students, and limitations in accessing school LSP in accordance with the competency skills in school, (2) the implementation of competency testing and certification can only be implemented in schools with the competency test (TUK) and a qualified assessor, and (3) financing relatively expensive when compared to other models.

Respondents to the planned development of a model of competence and certification testing computer networking students concluded that the availability of infrastructure facilities certification testing is currently rated $80.80 \%$ and $84.60 \%$ is sufficient need for the development of models assessed the existing certification test.

\section{b. The Devices Model of a Competency and International Certification Test}

Feasibility assessment module content content expert concluded that: (1) cover modules considered appropriate by the fourth validator (mean 100\%), (2) module objectives considered appropriate by the fourth validator (mean 100\%), (3) material module considered appropriate by three validator and the validator assessing appropriate (mean $97.32 \%)$, (4) training module is considered appropriate by the fourth validator (mean $100 \%$ ), (5) module is considered to be very precise discussion by two and two validator validator assess exact (mean $87.50 \%$ ), and (6) a reference list of modules assessed very precisely by three validator and the validator assessing less precise (mean $87.50 \%$ ), it can be said that there are components in the module as a whole is very precise used in model development and certification of competency test computer networking students, making it feasible to use.

Eligibility fill job sheet content expert assessment concluded that: (1) a cover sheet job very precisely assessed by the four validator (mean 100\%), (2) job sheet purposes considered appropriate by the fourth validator (mean 100\%), (3) assignment and time allocation sheets job assessed very precisely by the four validator (mean 100\%), (4) the study considered very appropriate job sheet by two and two validator validator assessing appropriate (mean 93.75\%), and (5) evaluation job sheet considered appropriate by the fourth validator (mean $100 \%$ ), it can be said that there are components in the overall job sheet is ideal to use in model development and certification of competency test students' computer networks, making it feasible to use.

c. The Developing a Model of a Competency and International Certification Test (UKOMSI SERINA)

At study end product, competency model development and certification testing computer network students experienced improvements after the implementation of the operational test and consideration of the educational actors. Starting from the study of existing models, and then developed a conceptual model, and after going through the stages of FGD, then the model is developed into a model of a hypothetical. Hypothetical model generated in this study, further limited testing and trials expanded. After review and evaluation of the implementation of the hypothetical models, eventually produced the final model testing and certification of competence.

The final model of a competency and computer network international certification test (UKOMSI SERINA), shown in Figure 1.

The developing a model of a competency and students computer network international certification test for vocational high schools, as in Figure 1 can be explained that, The model of a competency and students computer network international certification test (UKOMSI SERINA) for vocational high school students an available alternative models system of standardization of competency and certification test, with standard operating procedures as follows: (1) BSNP determine educational standards SMK (grad, content, process, educators and education personnel, facilities, management, education funding, and assessment of education); (2) establish standards of competence BNSP productive $S M K$ students. Both institutions are producing profiles of $S M K$ graduates who are competent to work in $\mathrm{Du} / \mathrm{Di}$, work independently (self-employed) and continued his studies. (3) a comprehensive vocational curriculum includes the following: graduate competency standards (SKL) $S M K$, educational norms, curriculum $D u / D i$, and the profile of $S M K$ graduates; (4) the learning process in the elaboration of the $S M K$ curriculum, the higher the class the more practices in the industry/workplace; (5) stages of teaching and learning $S M K$ students divided, into: (a) grade $\mathrm{X}$ students conducted teaching and learning process (PBM), (b) Grade XI students of semester 3 do Prakerin; (c) Grade XI students of semester 4 done TPA; (d) Grade XII students of semester 5, as well as ongoing PBM, students are also given the material practices of productive competence, andmaterials testing theory and practice of international certification. The end of Grade XII students of semester 5 exams conducted practice competencies and certification testing of international productive (coordination with the 
LSP). In Grade XII students of semester 6, respectively SMK students are given final exams (UAS), practice exams productive competence, and the UN; (6) students who graduate will receive a diploma and a certificate of competency and certification test, while students who do not pass will repeat the third grade and did not get a certificate of competency and certification test; (7) after graduation, a diploma and a certificate of competency and certification test held, students can work in accordance with the standards of $D u / D i$ or to continue their studies in college.

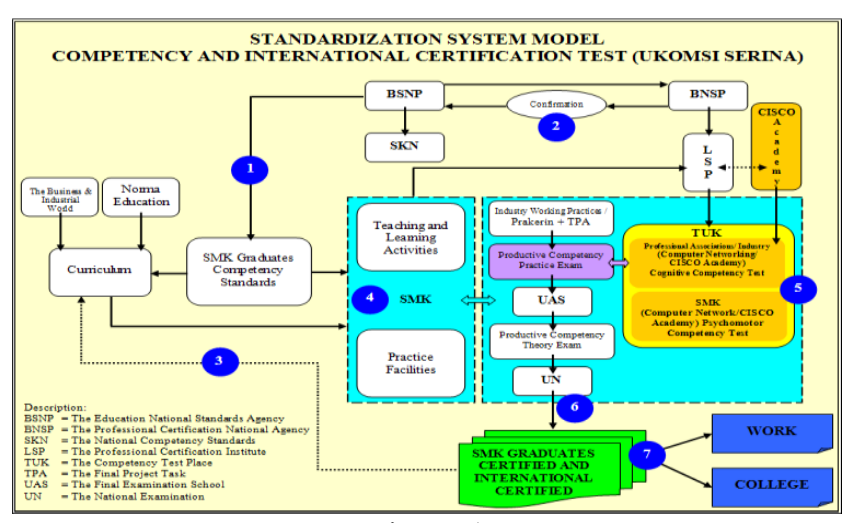

Figure 1

Final Model of a Competency and Computer Network International Certification Test

d. The Discussion of Devices Model of a Competency and International Certification Test

Discussion on the devices model of UKOMSI SERINA grouped into several sections, consisting of: (1) the data value of pretest and posttest, (2) the data value of cognitive, affective, and psychomotor, (3) student attitudes terhapan assessment data processes, materials, and instructors / teacher competency testing and certification, and (4) test data t-test on the pretest and posttest.

\section{Pretest and Posttest Data Value}

In Table 1 are presented the lowest value, the highest value and the mean pretest and posttest of a random sample of twenty of Grade XII students of semester 5 in an experimental class at SMK Negeri 1 Purwosari and SMK Negeri 2 Bojonegoro.

From Table 1 it can be concluded that the results for all values of pretest and posttest grade students on class field operational test experiments showed posttest mean value is greater than the average value of the pretest.

Table 1

Value Pretest and Posttest Score in Experiment Class

\begin{tabular}{|c|c|c|c|c|c|c|c|}
\hline \multirow[t]{3}{*}{ No. } & \multirow[t]{3}{*}{ Name of School } & \multicolumn{6}{|c|}{$\begin{array}{l}\text { Value of Knowledge Ability } \\
\text { Low, High, and Mean } \\
\text { at Pretest and Posttest }\end{array}$} \\
\hline & & \multicolumn{3}{|c|}{ Pretest } & \multicolumn{3}{|c|}{ Posttest } \\
\hline & & Min. & Max. & Mean & Min. & Max. & Mean \\
\hline \multirow{4}{*}{1.} & SMK Negeri 1 Purwosari & & & & & & \\
\hline & CCNA Discovery Module 1 & 40.91 & 84.09 & 57.61 & 36.36 & 100.00 & 77.39 \\
\hline & CCNA Discovery Module 3 & 21.43 & 57.14 & 34.17 & 23.81 & 100.00 & 76.07 \\
\hline & CCNA Discovery Module 7 & 29.55 & 68.18 & 45.68 & 20.45 & 100.00 & 80.11 \\
\hline \multirow{4}{*}{2.} & SMK Negeri 2 Bojonegoro & & & & & & \\
\hline & CCNA Discovery Module 1 & 18.18 & 54.55 & 37.05 & 31.82 & 100.00 & 77.84 \\
\hline & CCNA Discovery Module 3 & 14.29 & 35.71 & 27.50 & 19.05 & 100.00 & 66.67 \\
\hline & CCNA Discovery Module 7 & 22.73 & 52.27 & 37.50 & 25.00 & 100.00 & 72.05 \\
\hline
\end{tabular}

In Table 2 are presented the lowest value, the highest value and the mean pretest and posttest of a random sample of twenty of Grade XII students of semester 5 in a control class at SMK Negeri 1 Purwosari and SMK Negeri 2 Bojonegoro.

From Table 2 it can be concluded that the results for all values of pretest and posttest grade students on field operational test grade posttest control show the average value is greater than the average value of the pretest.

Table 2

Value Pretest and Posttest Score in Control Class

\begin{tabular}{|c|c|c|c|c|c|c|c|}
\hline \multirow[t]{3}{*}{ No. } & \multirow[t]{3}{*}{ Name of School } & \multicolumn{6}{|c|}{$\begin{array}{c}\text { Value of Knowledge Ability } \\
\text { Low, High, and Mean } \\
\text { at Pretest and Posttest }\end{array}$} \\
\hline & & \multicolumn{3}{|c|}{ Pretest } & \multicolumn{3}{|c|}{ Posttest } \\
\hline & & Min. & Max. & Mean & Min. & Max. & Mean \\
\hline \multirow{4}{*}{1.} & SMK Negeri 1 Purwosari & & & & & & \\
\hline & CCNA Discovery Module 1 & 31.82 & 72.73 & 51.14 & 31.82 & 97.73 & 57.84 \\
\hline & CCNA Discovery Module 3 & 21.43 & 47.62 & 31.31 & 16.67 & 97.62 & 40.83 \\
\hline & CCNA Discovery Module 7 & 20.45 & 68.18 & 40.11 & 18.18 & 100.00 & 43.07 \\
\hline \multirow{4}{*}{2.} & SMK Negeri 2 Bojonegoro & & & & & & \\
\hline & CCNA Discovery Module 1 & 20.45 & 61.36 & 37.61 & 20.45 & 86.36 & 62.05 \\
\hline & CCNA Discovery Module 3 & 19.05 & 38.10 & 26.67 & 26.19 & 88.10 & 52.62 \\
\hline & CCNA Discovery Module 7 & 18.18 & 50.00 & 35.80 & 27.27 & 77.27 & 59.43 \\
\hline
\end{tabular}

Information:

1. Min. =Lowest Value

2. Max. $=$ Highest Value

Data Value Cognitive, Affective, and Psychomotor Ability

In Table 3 and Table 4 are presented the value of students' abilities to cognitive, affective aspects, and aspects of psychomotor at SMK Negeri 1 Purwosari and SMK Negeri 2 Bojonegoro, the module 1, module 3 and module 7 competency test materials and international certification of computer networks students by integrating cognitive competency test and psychomotor competency test.

Data Assessment Student Attitudes toward Process, Content, and Instructor/Teacher Competency and Certification Test

Table 5 and Table 6 describes the frequency distribution of scores students 'attitudes toward the competence of testing and certification of computer networks by integrating test students' cognitive competence and psychomotor competency test.

$\underline{\text { Test Result Data t-test on the Pretest and Posttest }}$

Test data are shown in Table 7 describes the results of $t$ test analysis of pretest and posttest experimental class and control class at SMK Negeri 1 Purwosari and SMK Negeri 2 Bojonegoro.

Based on the data in Table 7 it can be said that, the results of the pretest value of experimental class and control class, either at SMK Negeri 1 Purwosari or at SMK Negeri 2 Bojonegoro same time significantly ( $\square \square$ ). It can be concluded that: (1) both the experimental class students and students in grade control at both schools, before product development models do have the same initial level of ability, and (2) the value of the test level of external validity through testing to students as test subjects showed the same results relevant to the properties or characteristics desired. 
Table 3

Value Connitive, Affective, and Psychomotor Ability at SMK Negeri 1 Purwosari

\begin{tabular}{|c|c|c|c|c|c|c|c|c|c|c|}
\hline \multirow{3}{*}{ No. } & \multirow{3}{*}{$\begin{array}{c}\text { CCNA } \\
\text { Discovery }\end{array}$} & \multicolumn{9}{|c|}{ Lowest, Highest, and Average Value } \\
\cline { 3 - 11 } & & \multicolumn{3}{|c|}{ Cognitive } & \multicolumn{3}{c|}{ Affective } & \multicolumn{3}{c|}{ Psychomotor } \\
\cline { 3 - 11 } & & Min. & Max. & Mean & Min. & Max. & Mean & Min. & Max. & Mean \\
\hline 1. & Module 1 & 56.25 & 75.00 & 70.63 & 60.00 & 75.00 & 70.50 & 70.00 & 75.00 & 73.50 \\
\hline 2. & Module 3 & 68.75 & 87.50 & 76.56 & 65.00 & 85.00 & 74.75 & 70.00 & 90.00 & 78.00 \\
\hline 3. & Module 7 & 68.75 & 81.25 & 76.56 & 60.00 & 85.00 & 73.75 & 70.00 & 85.00 & 75.00 \\
\hline \multicolumn{2}{|c|}{ The Mean Values } & 64.58 & 81.25 & 74.58 & 61.67 & 81.67 & 73.00 & 70.00 & 83.33 & 75.50 \\
\hline
\end{tabular}

Table 4

Value Cognitive, Affective, and Psychomotor Ability at SMK Negeri 2 Bojonegoro

\begin{tabular}{|c|c|c|c|c|c|c|c|c|c|c|}
\hline \multirow{3}{*}{ No. } & \multirow{3}{*}{$\begin{array}{l}\text { CCNA } \\
\text { Discovery }\end{array}$} & \multicolumn{9}{|c|}{$\begin{array}{l}\text { Lowest, Highest, and Average Value } \\
\text { in Aspect: }\end{array}$} \\
\hline & & \multicolumn{3}{|c|}{ Cognitive } & \multicolumn{3}{|c|}{ Affective } & \multicolumn{3}{|c|}{ Psychomotor } \\
\hline & & Min. & Max. & Rerata & Min. & Max. & & Min. & Max. & \\
\hline 1. & & & & & & & & & & \\
\hline 2. & & & 100 & 79. & 60.00 & & & & 95.00 & \\
\hline 3. & Module 7 & 1.50 & 93.75 & 79.69 & 65.00 & 95.00 & 78.75 & 50.00 & 95.00 & 76 \\
\hline \multicolumn{2}{|c|}{ The Mean Values } & 54.17 & 95.83 & 77.60 & 60.00 & 96.67 & 79.17 & 58.33 & 95.00 & \\
\hline
\end{tabular}

Information :

1. Min. $=$ Lowest Value

2. Max. $=$ Highest Value

Table 5

Assessment Attitudes toward Certification Process, Certification Material and Certification Teacher/Instructor Test at SMK Negeri 1 Purwosari

\begin{tabular}{|c|c|c|c|c|c|c|c|c|c|c|}
\hline \multirow{3}{*}{ No. } & \multirow{3}{*}{ Information } & \multicolumn{9}{|c|}{$\begin{array}{l}\text { Attitude Small Group } \\
\text { to: }\end{array}$} \\
\hline & & \multicolumn{3}{|c|}{$\begin{array}{l}\text { Certification } \\
\text { Process Test }\end{array}$} & \multicolumn{3}{|c|}{$\begin{array}{l}\text { Certification } \\
\text { Material Test }\end{array}$} & \multicolumn{3}{|c|}{$\begin{array}{l}\text { Certification Teacher/ } \\
\text { Instructor Test }\end{array}$} \\
\hline & & Score & f & $\%$ & Score & f & $\%$ & Score & f & $\%$ \\
\hline 1. & Very Positive & 5 & 6 & 30 & 5 & 6 & 30 & 5 & 5 & 25 \\
\hline 2. & Positif & 4 & 10 & 50 & 4 & 12 & 60 & 4 & 11 & 55 \\
\hline 3. & Doubtful & 3 & 4 & 20 & 3 & 1 & 5 & 3 & 4 & 20 \\
\hline 4. & Negative & 2 & 0 & 0 & 2 & 1 & 5 & 2 & 0 & 0 \\
\hline 5. & Very Negative & 1 & 0 & 0 & 1 & 0 & 0 & 1 & 0 & 0 \\
\hline & Total & & 20 & 100 & & 20 & 100 & & 20 & 100 \\
\hline
\end{tabular}

Table 6

Assessment Attitudes toward Certification Process, Certification Material and Certification Teacher/Instructor Test at SMK Negeri 2 Bojonegoro

\begin{tabular}{|c|c|c|c|c|c|c|c|c|c|c|}
\hline \multirow{3}{*}{ No. } & \multirow{3}{*}{ Information } & \multicolumn{9}{|c|}{$\begin{array}{c}\text { Attitude Small Group } \\
\text { to: }\end{array}$} \\
\hline & & \multicolumn{3}{|c|}{$\begin{array}{l}\text { Certification } \\
\text { Process Test }\end{array}$} & \multicolumn{3}{|c|}{$\begin{array}{l}\text { Certification } \\
\text { Process Test }\end{array}$} & \multicolumn{3}{|c|}{$\begin{array}{l}\text { Certification } \\
\text { Process Test }\end{array}$} \\
\hline & & Score & f & $\%$ & Score & $\mathrm{f}$ & $\%$ & Score & $\mathrm{f}$ & $\%$ \\
\hline 1. & Very Positive & 5 & 7 & 35 & 5 & 5 & 25 & 5 & 3 & 15 \\
\hline 2. & Positif & 4 & 12 & 60 & 4 & 12 & 60 & 4 & 16 & 80 \\
\hline 3. & Doubtful & 3 & 1 & 5 & 3 & 3 & 15 & 3 & 1 & 5 \\
\hline 4. & Negative & 2 & 0 & 0 & 2 & 0 & 0 & 2 & 0 & 0 \\
\hline 5 . & Very Negative & 1 & 0 & 0 & 1 & 0 & 0 & 1 & 0 & 0 \\
\hline & Total & & 20 & 100 & & 20 & 10 & & 20 & 100 \\
\hline
\end{tabular}

\section{Information:}

1. $\mathrm{f}=$ Frequency

2. $\%=$ Percentag

In Table 7 the data can also be said that, the value of posttest experimental class better control class, either at SMK Negeri 1 Purwosari or at SMK Negeri 2 Bojonegoro differ significantly $(p \leq \alpha)$. It can be concluded that: (1) both the experimental class students and students in the control class from each of the two schools, after the model and the models do have different levels of ability end, and (2) model and the test model of competence and certification of student computer network by integrating cognitive competency test and psychomotor competency test highly effective given in an attempt to increase the value of cognitive abilities students of SMK Negeri 1 Purwosari District, Pasuruan and SMK Negeri 2 Bojonegoro district, Bojonegoro in particular, as well as vocational courses computer engineering and network in the province of East Java in general.

Data t-test results between the pretest and posttest values were analyzed by using a different test (t-test) is as shown in Table 8, aims to determine the extent to which the efficiency of model development and certification of competency test students' computer networking, subjects computer networks on cognitive abilities and interests of students who have been tested on each school.

Based on the data in Table 8 can be said that the results of the experimental class posttest better value than the value of the pretest, both at SMK Negeri 1 Purwosari or at SMK Negeri 2 Bojonegoro differ significantly $(p \leq \alpha)$. It can be concluded that: (1) the experimental class students from each of the two schools, after the model and the models do have different levels of ability end, and (2) model and the test model of competence and certification of students by integrating computer networks competency test cognitive and psychomotor competency test highly efficient given in an attempt to increase the value of cognitive abilities students of SMK Negeri 1 Purwosari District, Pasuruan and SMK Negeri 2 Bojonegoro district, Bojonegoro in particular, as well as vocational courses computer engineering and network in the province of East Java in general

Table 7

Test Results of $\mathrm{t}$-test of Pretest and Posttest between Experiment and Control Class

\begin{tabular}{|c|c|c|c|c|c|c|c|c|c|c|c|c|c|}
\hline \multirow{4}{*}{ No. } & \multirow{4}{*}{ Schools } & \multicolumn{12}{|c|}{ The t-test Results Experiment and Control Class } \\
\hline & & \multicolumn{4}{|c|}{ Module 1} & \multicolumn{4}{|c|}{ Module 3} & \multicolumn{4}{|c|}{ Module7 } \\
\hline & & \multicolumn{2}{|c|}{ Pretest } & \multicolumn{2}{|c|}{ Posttest } & \multicolumn{2}{|c|}{ Pretest } & \multicolumn{2}{|c|}{ Posttest } & \multicolumn{2}{|c|}{ Pretest } & \multicolumn{2}{|c|}{ Posttest } \\
\hline & & $t$ & $p$ & $t$ & $p$ & $t$ & $p$ & $t$ & $p$ & $t$ & $p$ & $t$ & $p$ \\
\hline 1. & $\begin{array}{l}\text { SMK Negeri } 1 \\
\text { Purvosari }\end{array}$ & 1.985 & 0.054 & 3.686 & 0.001 & 1.185 & 0.243 & 4.943 & 0.000 & 1.831 & 0.075 & 5.359 & 0.000 \\
\hline 2. & $\begin{array}{l}\text { SMK Negeri } 2 \\
\text { Bojonegoro }\end{array}$ & -.173 & 0.863 & 2.568 & 0.014 & 0.420 & 0.677 & 2.182 & 0.037 & 0.678 & 0.502 & 2.308 & 0.027 \\
\hline
\end{tabular}

Table 8

Test Results of t-test of Pretest and Posttest in Experiment Class

\begin{tabular}{|c|c|c|c|c|c|c|c|}
\hline \multirow{2}{*}{ No. } & \multirow{2}{*}{ Schools } & \multicolumn{3}{|c|}{ Test Results of t-test of Pretest Posttest Experiment Class } \\
\cline { 3 - 8 } & & \multicolumn{2}{|c|}{ Module 1 } & \multicolumn{2}{|c|}{ Module 3 } & \multicolumn{2}{c|}{ Module 7 } \\
\cline { 3 - 8 } & & $t$ & $p$ & $t$ & $p$ & $t$ & $p$ \\
\hline 1. & SMK Negeri 1 Purwosari & -4.506 & 0.000 & -7.667 & 0.000 & -7.562 & 0.000 \\
\hline 2. & SMK Negeri 2 Bojonegoro & -9.068 & 0.000 & -7.026 & 0.000 & -7.553 & 0.000 \\
\hline
\end{tabular}

Information:

1. $t=$ Calculate The Value of $\mathrm{t}$

2. $p=$ Probability Values (SPSS: $p=\operatorname{Sig}$.

3. $p / 2=$ Sig. $(2$-tailed $)$

4. $\alpha \quad=$ Level of Significance $(5 \%=0.05)$

5. $p \geq \alpha=$ Received $\mathrm{H}_{0}$ Hypothesis

\section{Conclusion}

1. Implementation of competence and certification testing computer network students are currently assessed need for the development of the model, it is seen from the availability of infrastructure facilities implementing competency testing and certification of computer networks existing students, graded $80.80 \%$ and $84.60 \%$ is sufficient assessed need for the development of the model. 
2. Device models, such as: modules, job sheets and assessment system considered feasible by the content expert computer network for use, it is seen from the use of models of performance indicators, namely: mean score $92.67 \%$ eligibility module; feasibility job sheet $94.65 \%$, the validity of the test questions that have parallel value with standard test $(p \leq \alpha$ atau $0,000 \leq$ $0,05)$, and the coefficient alpha test instruments for about 0.891 .

3. The results of the operational test the model proved to be effective and efficient, it is seen that: (a) the value of pretest experimental class and control class together significantly $(p \geq 0,05)$ means that the student has the skill level and the same relevance to the properties or characteristics desired, (b) the value of better value pretest posttest in the experimental class was significantly $(p \leq 0,05)$ means that the student has a different level of late and very efficient, and (c) the value posttest experimental class better class control significantly $(p \leq 0,05)$ means that the student has a different level of end so it proved effective.

4. Ability and attitudes toward the implementation of the device models, concluded that: (a) the means good categories of the students' active competencies were: 74.58 for the cognitive aspect, 73.00 for the affective aspect, and 75.50 for the psychomotor aspect, and (b) the students' attitudes towards: the certification test process were positive $(80 \%)$, the materials of the certification test were positive (90\%), and the instructors/teachers of the certification test were positive $(80 \%)$.

\section{References}

[1] Badan Pusat Statistik. (2012). Penduduk 15 Tahun ke Atas yang Bekerja menurut Lapangan Pekerjaan Utama, 2004-2012. Diunduh pada tanggal 10 Maret 2013, dari http://www.bps.go.id/tab_sub/view.php?kat=1\&tabel=1\&daftar=1\&i d_subyek $=06 \&$ notab $=2$

[2] Borg, W. R. \& Gall, M. D. (1983). Educational research: An introduction $\left(4^{\text {th }} \mathrm{ed}\right.$.). New York: Longman.

[3] Briggs, Leslie, J. (1977). Instructional design: principles and application. Englewood Cliffts, New York: Longman, Inc.

[4] Budi Santosa. (2009). Model uji kompetensi di SMK. Penelitian. Diunduh pada tanggal 10 Maret 2013, dari http://www.google.co.id/ url?sa=t\&rct=i\&q=\&esrc=s\&source=we \& $\mathrm{cd}=1 \& \mathrm{cad}=\mathrm{rja}$

[5] Dedy Suryadi. (2003). Pengembangan model uji kompetensi dalam kurikulum berbasis kompetensi pada SMK kelompok teknologi dan industri. Seminar nasional implementasi kurikulum SMK 2004 dan harapan dunia industri. Diunduh pada tanggal 10 Maret 2013, dari http://www.google.co.id/url?sa=t\&rct=j\&q=\&esrc=s\&source=web\& $\mathrm{cd}=1 \& \mathrm{cad}=\mathrm{rja} \&$

[6] Depdiknas. (2004). Direktori lembaga sertifikasi profesi dan tempat uji kompetensi. Jakarta: Direktorat Jendral Pendidikan Dasar dan Menengah.

[7] Dindik. Jatim. (2012). Program pembinaan Sekolah Menengah Kejuruan. Diunduh pada tanggal 10 Maret 2013, dari http://pusatdata.dindikjatim.net/ ?p=progra $m$ \&idm $=11$

[8] Enoch, Yusuf. (1992). Dasar-dasar perencanaan pendidikan. Jakarta: Bumi Aksara.

[9] Gunawan, Ricky. (2006). Relevansi kompetensi lulusan SMK dengan tuntutan dunia kerja. Makalah. Diunduh kembali pada tanggal 10 Maret 2013, dari http://file.upi.edu/
Direktori/FPTK/JUR. PEND. TEKNIK MESIN/195105011980021 -RICKY GUNAWAN/MAKALAH_SEMNAS_PTK 2006.pdf

[10] Parry, S. B. (1996). The quest for competencies: Competency studies can help you make HR decision. Journal of Training, 33, 48-55.

[11] Perkins D., C. (1998). The Carl D. Perkins vocational and technical education act, Public Law 105-332. New York: U.S. Department od Education. Diunduh pada tanggal 20 Agustus 2011, dari http://www. ed.gov/offices/OVAE/CTE/perkins. html. 3-8.

[12] Samsudi, dkk. (Mei 2009). Peningkatan kualitas dan hasil uji kompetensi siswa dalam rangka ujian nasional SMK. Makalah disajikan dalam Seminar Internasional APTEKINDO, di Padang.

[13] Walter. (1993). The vocatiobal educations. Penelitian. Diunduh pada tanggal 16 Agustus 2011, dari http://www.krannert. purdue.edu/konline/fall2009/krannertData/chair.asp

[14] Wardiman Djojonegoro. (1998). Pengembangan sumber daya manusia: Melalui sekolah menengah kejuruan (SMK). Jakarta: PT Balai Pustaka.

[15] Yusufhadi Miarso. (1987). Survai model pengembangan instruksional. Laporan Penelitian. Jakarta: Ditjen DIKTI Proyek Pengembangan Pusat Fasilitas Bersama Antar Universitas.

[16] Zainur Rofiq. (2002). Pengembangan model perangkat uji kompetensi spesifik di sekolah menengah kejuruan (SMK) teknologi untuk mendukung sertifikasi teknisi industri di bidang permesinan. Artikel. Diunduh pada tanggal 10 Maret 2013, dari http://www.google.co.id/url?sa= t\&rct=j\&q=\&esrc=s\&source=web $\& c d=1 \& c a d=r j a \& v$. 